\title{
Treatment Failure of Ampicillin to Children with Pneumonia at Dr. Hasan Sadikin General Hospital Bandung from 2014-2015
}

\author{
Kania Devi Suharno, ${ }^{1}$ Ike Rostikawati Husen, ${ }^{2}$ Sri Sudarwati ${ }^{3}$ \\ ${ }^{1}$ Faculty of Medicine Universitas Padjadjaran, ${ }^{2}$ Department of Pharmacology and Therapy \\ Faculty of Medicine Universitas Padjadjaran, ${ }^{3}$ Department of Child Health Faculty of Medicine \\ Universitas Padjadjaran/Dr. Hasan Sadikin General Hospital, Bandung
}

\begin{abstract}
Background: Pneumonia is one of the causes of death in infants in developing countries especially Indonesia. Appropriate treatment is needed to decrease mortality rate in children due to pneumonia. Ampicillin is one of first choices empirical antibiotic to children with severe pneumonia. The study was aimed to determine the failure rate of ampicillin in children with severe pneumonia.

Methods: This study was a descriptive study which used medical records as source of data. Subjects were children aged 2-59 months with World Health Organization (WHO) defined with severe pneumonia and treated with intravenous ampicillin during January 2014 to July 2015 at Dr. Hasan Sadikin General Hospital Bandung. Samples were obtained using total sampling method while variables were analyzed using statistics software.

Results: This study acquired 107 patients who met the inclusion criteria with $23.36 \%$ of them aged 2-11 months and $62.21 \%$ aged $12-23$ months. Majority of subjects were male amounted as $63.55 \%$ while female occupied $36.45 \%$. Treatment failure on the third day was $45.8 \%$ while $16.7 \%$ on the sixth day of therapy with majority failure due to existence of lower chest indrawing.

Conclusions: Treatment failure on the third and sixth day of therapy still high that is characterized by the existence of lower chest indrawing as its main factor. [AMJ.2017;4(1):100-6]
\end{abstract}

Keywords: Ampicillin, pneumonia, treatment failure

\section{Introduction}

Pneumonia is a kind of lung infection characterized by inflammation of the lung parenchyma tissue caused by infection agents such as viruses and bacteria. ${ }^{1,2}$ In Indonesia, pneumonia is a leading cause of death in children less than 5 years old. An increase of period prevalence from $2.1 \%$ to $2.7 \%$ occurred in 2013. ${ }^{3}$ Most common pathogen in children less than 5 years old are Streptococcus pneumoniae and Haemophillusinfluenzae. ${ }^{1,4,5}$ Recent studies were conducted in Indonesia, as many as $67.8 \%$ Streptococcus pneumoniae in nasopharyngeal specimens in children aged 2-5 years old with pneumonia. ${ }^{6}$ Death due to pneumonia which is caused by Streptococcus pneumoniae and Haemophillus influenzae are $32.7 \%$ and $15.7 \%$ respectively. ${ }^{4}$

Resistance to antibiotics is one of the causes of high mortality rate. ${ }^{7}$ In Asia, 30.1\% of Streptococcus pneumoniae is resistant to penicillin. Effectiveness of ampicillin against Haemophillusinfluenzae is $68.7 \%$, therefore the value reflected decreasing ability of ampicillin against Haemophillusinfluenzae. ${ }^{8}$ This should be a concern since Streptococcus pneumoniae and Haemophillusinfluenzae are the most frequent bacteria causing Community Acquired Pneumonia (CAP) in children aged 2-59 months with ampicillin as the first line therapy choice. ${ }^{1,2}$ Different outcome is represented by the study in Lombok which showed that serogroup of non-susceptible Streptococcus pneumoniae to penicillin could reach $2.2 \%{ }^{6}$ A study conducted in Pakistan ${ }^{9}$ among children aged 2-59 months with clinical symptoms of pneumonia such as lower chest indrawing and rapid breathing that had treatment failure of intravenous ampicillin

Correspondence: Kania Devi Suharno, Faculty of Medicine, Universitas Padjadjaran, Jalan Raya Bandung-Sumedang Km.21, Jatinangor, Sumedang, Indonesia, Phone: +6282117797706 Email: devi.kania@gmail.com 
was $5.8 \%$ on third day and $8.6 \%$ on sixth day of therapy. ${ }^{9}$

The study realized the importance of researching about treatment failure of ampicillin in children with pneumonia due to its increase prevalence, high mortality and the most common etiology such as Haemophillusinfluenzae was resistant to ampicillin. In Indonesia, treatment failure rate has not been reported; therefore, this study aimed to determine treatment failure of intravenous ampicillin in children with severe pneumonia aged 2-59 months, exclusively patients who were treated in Kenanga Room at Dr. Hasan Sadikin General Hospital Bandung from year 2014 to 2015.

\section{Methods}

This descriptive study was conducted at Dr. Hasan Sadikin General Hospital Bandung from $3^{\text {rd }}$ September to $20^{\text {th }}$ November 2015. Data used in this study were secondary data from medical records of patients who were treated in Kenanga Room at Dr. Hasan Sadikin General Hospital Bandung from January 2014 to July 2015. This study was conducted after obtaining the approval from Health Research Ethics Committee of Dr. Hasan Sadikin General Hospital Bandung, No: LB.04.01/A05/EC/232/VII/2015. Method of sampling was conducted by total population method. Minimum sample that required in this study were 97 subjects based on sample size calculation for descriptive study with categorical variables. Sample criteria were children aged 2-59 months who met the category by World Health Organization (WHO) defined with severe pneumonia and treated by intravenous ampicillin. Severe pneumonia was categorized for patient with rapid breathing (aged 2-11 months: $\geq 50$ beats/minute, aged 11-59 months: $\geq 40$ times /minute) and lower chest indrawing. Patients with danger signs of very severe pneumonia such as cyanosis, inability to breastfeeding, vomiting everything, loss of consciousness, convulsions, and severe respiratory distress (aged 2-11 months: $\geq 60$ beats/minute, age 11-59 months: $\geq 50$ times / minute) were excluded from this study. Patient with malnutrition, congenital heart disease, tuberculosis, and asthma are also excluded.

Variables observed in this research were age, gender, birth weight, up to date immunization, breast feeding, report of antibiotics use in past 7 days, referral status, treatment failure rate at third and sixth day of treatment, antibiotic therapy, and the duration of hospitalization. Immunization status was defined as the conformity between children age and immunization received according to the health ministry program. Exclusive breastfeeding was defined as breastfeed for 6 months without other additional food. Treatment failure was determined by looking at patient's clinical symptoms on third and sixth day whether lower chest indrawing, rapid breathing, signs of very severe pneumonia, death, and fever over $38^{\circ} \mathrm{C}$ occurred. Treatment failure was monitored on third day due to the possibilities of the pathogens which caused pneumonia were susceptible to ampicillin, hence, the clinical symptoms should be improved consequently until the sixth day as the subject recovered. Variables were analyzed using statistics software.

\section{Result}

Total patients with diagnosis of bronchopneumonia with International Classification of Disease (ICD) criteria J.18.0 (bronchopneumonia with unspecified organism) during the period of January 2014 to August 2015 were 616 patients. Subjects from January to August 2015 were 191 and 425 subjects from January to December 2014. As of 191 subjects in year 2015, there were 37 subjects met the inclusion criteria, 3 medical records missed, and 151 subjects excluded. From 425 subjects in year 2014, there were 70 subjects met the inclusion criteria, 32 medical records missed, and 323 subjects excluded; therefore, 107 subjects were obtained from January 2014 to August 2015. Clinical manifestation of subjects who met inclusion criteria was recorded until subject recovered and dismissed from hospital.

Based on this study result, median value on the subject aged was 12 months, with minimum aged was 2 months and maximum aged was 48 months. From 15 subjects who have history of antibiotics usage on the previous week, 5 of them were using amoxicillin (Table 1).

On the third day, subjects who experience treatment failures were about 49 subjects from 107 population subjects; hence, the treatment failure on third day was $45.8 \%$ which is figured on table 2 . The indicators of treatment failure mostly were marked by the existence of lower chest indrawing on 37 subjects and rapid breathing on 27 subjects. Total subjects who have signed of very severe pneumonia were 9 subjects so that they received antibiotics replacement. There were 2 subjects who exceeded normal body temperature $\left(\geq 38^{\circ} \mathrm{C}\right)$ 
Table 1 Characteristics of Subject

\begin{tabular}{|c|c|}
\hline Characteristics & Total (\%) \\
\hline \multicolumn{2}{|l|}{ Age (months) } \\
\hline $2-11$ & $25(23.36 \%)$ \\
\hline $12-23$ & $67(62.61 \%)$ \\
\hline $24-35$ & $9(8.41 \%)$ \\
\hline $36-47$ & $2(1.86 \%)$ \\
\hline $48-59$ & $4(3.73 \%)$ \\
\hline \multicolumn{2}{|l|}{ Sex } \\
\hline Male & 68 (63.55\%) \\
\hline Female & $39(36.45 \%)$ \\
\hline \multicolumn{2}{|l|}{ Birth weight (gram) } \\
\hline$<2500$ & $7(6.54 \%)$ \\
\hline$\geq 2500$ & $42(39.25 \%)$ \\
\hline Unknown & $58(54.2 \%)$ \\
\hline \multicolumn{2}{|l|}{ Immunization status } \\
\hline Yes & 79 (73.38\%) \\
\hline No & $19(17.75 \%)$ \\
\hline Unknown & $9(8.41 \%)$ \\
\hline \multicolumn{2}{|l|}{ Exclusive Breastfeeding } \\
\hline Yes & $72(67.28 \%)$ \\
\hline No & $24(22.42 \%)$ \\
\hline Unknown & $11(10.28 \%)$ \\
\hline \multicolumn{2}{|l|}{ Report of antibiotic use in past 7 days } \\
\hline Yes & $15(14 \%)$ \\
\hline No & 0 \\
\hline Unknown & $92(86 \%)$ \\
\hline \multicolumn{2}{|l|}{ Referral } \\
\hline Yes & $55(51.4 \%)$ \\
\hline No & $52(48.6 \%)$ \\
\hline
\end{tabular}

and 1 subject passed away on the third day (Table 2).

There were 9 subjects who experienced treatment failure on the third day due to very severe pneumonia who changed antibiotic and one subject passed away. Both of those 10 subjects were excluded thus the number of subject on this study became 97 peoples on the sixth day (Table 3).

Subjects who had duration of hospitalization were less than six days and otherwise cured by doctor, then inserted into group of patients who had success treatment because the patients dismissal from hospital were linked to the absence of lower chest indrawing, no rapid breathing, no fever, and subjects were able to drink and eat. Hence, there were 67 patients who underwent treatment success before day 6 (Table 4).

On the sixth day, total subjects were 97 peoples, 16 subjects had treatment failure, so the treatment failure rate was $16.5 \%$. Treatment failure on the sixth day was characterized by the existence of lower chest indrawing, rapid breathing, and sign of very severe pneumonia such as severe respiratory 
Table 2 Treatment Failure on $3^{\text {rd }}$ day

\begin{tabular}{lc}
\hline \multicolumn{1}{c}{ Treatment failure on 3rd day } & $\mathbf{N}$ \\
\hline Lower chest indrawing & 13 \\
Rapid breathing & 10 \\
Very severe pneumonia & 9 \\
Any danger sign & \\
$\quad$ Existence of: & 16 \\
$\quad$ Lower chest indrawing and rapid breathing & 5 \\
$\quad$ Lower chest indrawing and sign of very severe pneumonia & 1 \\
$\quad$ Lower chest indrawing, rapid breathing, and death & 2 \\
Lower chest indrawing, sign of very severe pneumonia, and fever & $49(45.8 \%)$ \\
\hline
\end{tabular}

Table 3 Antibiotic Therapy

\begin{tabular}{|c|c|}
\hline Antibiotic & $\mathrm{n}$ \\
\hline Ampicillin & 97 \\
\hline Changed antibiotic & 9 \\
\hline Total & 106 \\
\hline
\end{tabular}

Table 4 Length of Stay

\begin{tabular}{|c|c|}
\hline Length of stay & $\mathbf{n}$ \\
\hline$<6$ days & 67 \\
\hline$\geq 6$ days & 30 \\
\hline Total & 97 \\
\hline
\end{tabular}

distress. Most of treatment failure were marked by lower chest indrawing and experienced by 10 subjects. Antibiotic replacement was needed for 8 subjects and there were no subjects who had fever.

\section{Discussion}

Based on this study result, the highest incidence of bronchopneumonia among children occurred from age 12 to 23 months which was occupied by $67(62.6 \%)$ subjects. These findings are in line with the result of National Health Research (Riset Kesehatan Dasar, Riskesdas) which was held by Indonesian Ministry of Health 2013 that showed high occurrence of bronchopneumonia among children happened among children aged 12 to 23 months. Nevertheless, this result is slightly different with study conducted in Pakistan ${ }^{9}$ where majority of study subject amounted
$64 \%$ were aged 3 to 11 months. ${ }^{9}$

The result presented that based on gender, study subjects were dominated by males as many as 68 subjects (63.55\%). Analogous with another study among children in Pakistan ${ }^{9}$ with $60.4 \%$ subject are males. Study conducted in Bangladesh ${ }^{10}$ presented $56.5 \%$ subjects are males. Although the results acquired more subjects are males, but the different number of subjects was not significant.

Treatment failure rate on the third day reached $45.8 \%$. This result is much higher than similar study conducted in Pakistan ${ }^{9}$ where treatment failure on third day was $5.8 \%$. Study in Pakistan ${ }^{9}$ showed that subject with history of previous antibiotics usage could increase treatment failure rate due to the possibilities of pathogen which were resistant or stronger. Subjects on this study who had history of previous antibiotics and experiencing treatment failure on the third 
Table 5 Marked of Treatment Failure on 6th day

\begin{tabular}{lc}
\hline \multicolumn{1}{c}{ Treatment failure on $\mathbf{6}^{\text {th }}$ day } & $\mathbf{N}$ \\
\hline Lower chest indrawing & 1 \\
Rapid breathing & 3 \\
Very severe pneumonia & 3 \\
Any danger sign & 4 \\
$\quad$ Lower chest indrawing and rapid breathing & 5 \\
$\quad$ Lower chest indrawing and very severe pneumonia & $16(16.5 \%)$ \\
Total & \\
\hline
\end{tabular}

day were $5(33.3 \%)$ subjects.

High failure treatment rate might be initiated by the change of pathogen that not susceptible to ampicillin. Another possibility was etiology of pneumonia caused by serogroup Streptococcus pneumoniae that was resistant against ampicillin. Dosage of intravenous ampicillin was $25-50 \mathrm{mg} / \mathrm{kg}$ per injection every 6 hours. Accordingly, the minimum inhibitory concentration (MIC) for susceptible bacteria reached from peak concentration until the last half life $(\geq 0.12 \mathrm{mcg} / \mathrm{ml}){ }^{2,11}$ The causal factor that induced high treatment failure could not ascertained because subjects did not do lung aspiration and test for antibiotic resistance.

On the sixth day of therapy, subjects experienced treatment failure as many as 16 $(16.5 \%)$ peoples. Another study performed in Pakistan $^{9}$ acquired treatment failure in sixth day was $8.6 \%$. The indicators of treatment failure mostly were marked by the existence of lower chest indrawn in $10(62.5 \%)$ subjects. The studies performed in Pakistan and other countries had similar results which stated that lower chest indrawing is the indicator of treatment failure. ${ }^{9,12}$ Inflammation of the lung parenchyma in children with pneumonia causes dysfunction in blood oxygen exchange then induces hypoxemia. Peripheral chemoreceptor located in the carotid body is very sensitive to changes in blood oxygen levels. When hypoxemia occurs, the carotid body will induce respiratory central controller to increase the rate of breathing. In children, respiratory muscle fibers are composed of many types of 2 muscle fibers which are easily exhausted that will induce use of respiratory accessory muscle. The use of accessory muscle is characterized by clinical sign of lower chest indrawing. ${ }^{1}$

Based on the age, as many as $6(24 \%)$ subjects aged $2-11$ months and 9 subjects aged $12-23(13.4 \%)$ months experienced failure treatment on the sixth day. Subjects with age less than 12 months had a tendency to experience treatment failure. ${ }^{9,13-15}$ The reasons of treatment failure in young infant can be caused by smaller airway, more compliant chest wall and poor hypoxic driver. These make young infant become vulnerable to respiratory disease. ${ }^{1}$

Subjects aged less than 24 months and exclusively breastfed failed during treatment on the sixth day as many as 8 (19\%) subjects. Previous study stated that exclusive breastfeeding could decrease the risk of treatment failure on the sixth day in children aged less than 24 months. . $^{916,17}$ This phenomenon happened because the exclusive breastfeeding itself could increase selfimmunity as natural antimicrobial. ${ }^{18}$

Children with exclusive breastfeeding as many as $46(63.8 \%)$ of 72 subjects were hospitalized less than 6 days. Previous study conducted at Dr. Hasan Sadikin General Hospital Bandung to children with severe pneumonia described that children with exclusive breastfeeding had shorter duration of hospitalization. ${ }^{19}$ Exclusive breastfeeding can avoid pneumonia and lower the risk of morbidity or even mortality due to pneumonia among children aged less than 24 months. ${ }^{16,17}$ Exclusive breastfeeding itself has natural antimicrobial effect which can fight against infection caused by Streptococcus pneumonia; hence, exclusive breastfeeding is able to improve effectiveness of antibiotics, decrease MIC (Minimum Inhibitory Concentration), and also reduce time needed to kill bacteria. ${ }^{18}$

Other study showed that children with severe pneumonia treated with high dose amoxicillin is $80-90 \mathrm{mg} / \mathrm{kg}$ per oral every 12 hours had similar failure rate with intravenous ampicillin. ${ }^{9} \quad$ This is quite interesting considering that 5 subjects in this study had history of amoxicillin oral treatment for three 
days, however, the dose given to the patients is unknown.

The high failure rate indicated the need for further research in treatment of children with severe pneumonia which considered effective and efficient. Study about treatment using combination of antibiotics is considered due to the killing effects of antibiotics that are faster, lowering the cytokines inflammation, and can attack organism with broader spectrum. ${ }^{20}$

Limitations of this study are the data used were secondary data so that some of the data such as report of antibiotic use in past 7 days, birth weight, up to date immunization and breastfeeding that are not listed on the medical record could not be processed.

Ampicillin still has high failure rate because of the existence of lower chest indrawing during treatment. The failure rate is still high representing lack of effectiveness of treatment intravenous ampicillin in children with severe pneumonia. Hence, it requires further research regarding to effective antibiotic for severe pneumonia treatment in children.

\section{References}

1. Kliegman RM, Stanton BF, Schor NF. Community acquired pneumonia (CAP). In: Gatsch M, Dimock K, Shreiner J, Tannian P, editors. Nelson Textbook of Pediatrics. 20th ed. Philadelphia: Elsevier; 2015. p. 2089-94.

2. WHO. Pocket book of hospital care for children, guidelines for the management of common illnesses with limited resources. Switzerland: WHO; 2005. p. 72-80.

3. Kementerian Kesehatan RI. Laporan hasil riset kesehatan dasar (riskesdas) Indonesia tahun 2013. Jakarta: Badan Penelitian dan Pengembangan Kesehatan; 2013. p. 66-8.

4. Rudan I, O’Brien KL, Nair H, Liu L, Theodoratou E, Qazi S, et al. Epidemiology and etiology of childhood pneumonia in 2010: estimates of incidence, severe morbidity, mortality, underlying risk factors and causative pathogens for 192 countries. J Glob Health. 2013;3(1):10410.

5. Honkinen M, Lahti E, Osterback R, Ruuskanen $\mathrm{O}$, Waris $\mathrm{M}$. Viruses and bacteria in sputum samples of children with community-acquired pneumonia. Clin Microbiol Infect. 2012;18(3):300-7.

6. Bravo L. Overview of the disease burden of invasive pneumococcal disease in Asia. Vaccine. 2009;27(52):7282-91.
7. Galli L, Montagnani C, Chiappini E, de Martino M. Treating paediatric community-acquired pneumonia in the era of antimicrobial resistance. Acta Paediatr Suppl. 2013;102(465):25-33.

8. Tomic V, Dowzicky M. Regional and global antimicrobial susceptibility among isolates of Streptococcus pneumoniae and Haemophilusinfluenzae collected as part of the Tigecycline Evaluation and Surveillance Trial (T.E.S.T.) from 2009 to 2012 and comparison with previous years of T.E.S.T. (2004-2008). Ann Clin Microbiol Antimicrob. 2014;13(1):52-8.

9. Hazir T, Fox LM, Nisar YB, Fox MP, Ashraf YP, MacLeod WB, et al. Ambulatory short course high dose oral amoxicillin for treatment of severe pneumonia in children: a randomised equivalency trial. Lancet. 2008;371(9606):49-56.

10. Chisti MJ, Salam MA, Ahmed T, Shahid AS, Shahunja KM, Faruque ASG, et al. Lack of BCG vaccination and other risk factors for bacteraemia in severely malnourished children with pneumonia. Epidemiol Infect. 2015;3(4):799-803.

11. Katzung BG, Masters SB, Trevor AJ. Betalactam and other cell wall- and membraneactive antibiotics. In: Akporiaye ET, AminoffMJ, Basbaum AI, editors. Basic and Clinical Pharmacology. 12th ed. San Francisco: McGraw-Hill Education; 2012. p. 790-808.

12. Addo-Yobo E, Anh DD, El-Sayed HF, Fox LM, Fox MP, MacLeod W, et al. Outpatient treatment of children with severe pneumonia with oral amoxicillin in four countries: the MASS study. Trop Med Int Health. 2011;16(8):995-1006.

13. Jain DL, Sarathi V, Jawalekar S. Predictors of treatment failure in hospitalized children 3-59 months with severe and very severe pneumonia. Indian Pediatr. 2013;50(8):787-9.

14. Agweyu A, Kibore M, Digolo L, Kosgei C, Maina V, Mugane S, et al. Prevalence and correlates of treatment failure among kenyan children hospitalised with severe community-acquired pneumonia: a prospective study of the clinical effectiveness of WHO pneumonia case management guidelines. Trop Med Int Health. 2014;19(11):1310-20.

15. Basnet S, Sharma A, Mathisen M, Shrestha PS, Ghimire RK, Shrestha DM, et al. Predictors of duration and treatment failure of severe pneumonia in hospitalized young nepalese children. PloS one. 
2015;3(3):1-11.

16. Amberti LM Z-GI, Fischer Walker C,L., Theodoratou E, Nair H, Campbell H, et al. Breastfeeding for reducing the risk of pneumonia morbidity and mortality in children under two: a systematic literature review and meta-analysis. BMC Public Health. 2013;13(3):1-8.

17. BarsamFJBG, Borges GSD, Severino ABA, Mello LMd, Silva ASd, Nunes AA. Factors associated with community-acquired pneumonia in hospitalised children and adolescents aged 6 months to 13 years old. Eur J Pediatr. 2013;172(4):493-39.

18. Marks LR CE, Hakansson AP. The human milk protein-lipid complex HAMLET sensitizes bacterial pathogens to traditional antimicrobial agents. PloS one. 2012;7(8):1-7.

19. Nataprawira HM, Alwi EH, Adriani N. Faktor Risiko Morbiditas dan Mortalitas Pneumonia Berat pada Anak Usia Balita. Maj Kedokt Indones. 2010;60(10):443-7.

20. Majhi A, Kundu K, Adhikary R, Banerjee M, Mahanti S, Basu A, et al. Combination therapy with ampicillin and azithromycin in an experimental pneumococcal pneumonia is bactericidal and effective in down regulating inflammation in mice. J Inflamm (Lond). 2014;11(1):5-49. 